\title{
KÖZELKÉP
}

\section{Hatékonyan hatni az emberekre - \\ avagy kell-e, szabad-e manipulatív hatásokkal élniük a segítő szakembereknek?*}

\author{
KRÉMER BALÁZS ${ }^{1}$
}

\begin{abstract}
ABSZTRAKT
Az elmúlt két évtized gazdasági és politikai válságaihoz nagyban hozzájárult az, hogy különféle manipulatív hatásoknak engedve az emberek józan eszük és racionális gondolkodásuk helyett döntéseiket különféle érzelmi és ösztönös alapú csábítás, félrevezetés hatása alatt hozták meg. Mára e manipulatív hatások uralják a kereskedelmi vagy a populista politikai kommunikációt. Az alábbi dolgozat a szerző hezitálását osztja meg arról, hogy miközben mind az emberek döntéshozatalában, mind a másik emberre gyakorolt kommunikatív hatások körében nemhogy megkerülhetetlenül jelen vannak a racionális mérlegeléstől és érveléstôl eltérő, nem racionális tényezốk is - de, vajon szabad-e egyáltalán ilyen manipulatív hatásokkal élniük az ügyfeleikre gyakorolt hatásgyakorlásuk közben a segítö szakembereknek? És ha bármiben is igen, akkor milyen feltételek mellett, milyen speciális korlátokat betartva szabad élni az ilyen hatásokkal, az ilyen hatások „hatalmával”? Ugyanígy: vajon mikor mit lehet és kell tenni a manipulatív hatások enyhítésére, az azok alól felszabadító, bölcs döntésekhez segítő józan ész térnyeréséhez, a racionális mérlegelés alapján történő felelős „képessé tevésre”? A cikk nem vállalkozik az igaz és helyes válaszok megadására, szempontokat ad és igyekszik olvasóját arra provokálni, hogy járuljon hozzá e fontos probléma tisztázásához.
\end{abstract}

KULCSSZAVAK: racionalitás, hatás, manipuláció, segítő szakmák/szociális munka

\section{ABSTRACT}

\section{Effectively influence on people - or are helping professionals free to utilize manipulative impacts?}

The economic and political crises of the last two decades have been greatly influenced by the fact that, impacted by manipulative effects, instead to follow their rational judgements people have made their decisions under the influence of emotional and instinctive temtation, deception and manipulation. So far, these manipulative influences dominate contemporary commercial or po-

* A tanulmány a Horizon 2020 Program ACCOMPLISSH (Accelerate co-creation by setting up a multiactor platform for impact from Social Sciences and Humanities) című projekt keretében készült. A támogatás száma: 693477. szék.

${ }^{1}$ Egyetemi docens, Debreceni Egyetem, Bölcsészettudományi Kar, Szociológia és Szociálpolitika Tan- 


\section{KÖZELKÉP}

pulist political communication. The paper below shares the author's hesitation that, while non-rational factors bias from rational arguing and reasoning, both in decision-making and in communicative impacts on the other person inevitably present, is it acceptable to manipulate the users/clients by assisting professionals/social workers while exercising influence on decision-making of their clients? And if so, under what conditions, what specific constraints could be exercised such impacts and "professional power"? Likewise, when and what can and should be done to immunize clients against manipulation, to mitigate manipulative effects, to "gain back" rational mind and "empower" clients to follow rational consideration and make wiser decisions? The article does not undertake to provide „only” true and correct answers, rather gives insights and tries to provoke its reader to contribute to clarifying this important issue.

KEYWORDS: rationality, impact, manipulation, assisting professions/social work

\section{Bevezetés gyanánt - az ember másképp dönt, másképp múködik, mint azt szokás volt feltételezni}

Az elmúlt években kutatói munkám során döntően a válsághoz vezető és a válság utáni világ „újratervezése” foglalkoztatott. Annak a megfejtése, hogy hogyan sodródhatott az emberiség olyan tömeges „elhülyülésbe”, amely a felelőtlen hitelfelvételek nyomán a világ gazdaságát megrendítő hitelválságba torkollott, vagy hogy mitől nyerhettek ennyi szavazatot hétpróbás gazember populisták szabad és demokratikus választásokon (Krémer 2016, 2018a, 2018b)?

Nem mondanám, hogy kerek megfejtéssel tudok szolgálni, de számos részmagyarázatra azért jutottam - ezek egy hányadát korábbi publikációimban is igyekeztem ismertetni.

A magyarázataimban a legfontosabb kiindulási alapot a magatartástudomány és a magatartási közgazdaságtan eredményei jelentették nemcsak nekem, de sokaknak, másoknak is. (Nyilván, ezt jelzi az egyik legjelentősebb magatartási közgazdász, Richard Thaler 2017. évi közgazdasági Nobel-díja is.) Sokáig a behaviorista irányzat afféle egzotikus mellékága volt a közgazdaságtudománynak és a pszichológiának - talán épp azok miatt a forradalmi alapvetéseik miatt, amelyek a reneszánsz óta mindmáig uralkodó emberképet kérdőjelezték meg. A modernitás domináns antropológiai képzete az embert racionálisan haszonelvű lényként képzelte el. Ez a racionális ember, a „homo eoconomicus” amikor dönt, akkor a legnagyobb valószínűséggel a legnagyobb haszonnal kecsegtető (a legnagyobb veszteség elkerülését eredményező) lehetőségeket választja döntésként. Ugyancsak e képzet szerint, bár olykor ez nem sikerül neki, de a racionálisan haszonelvű döntésektől való eltérések véletlenek, amely hibák és eltérések az emberek „átlagos” magatartásában kioltják, kiegyenlítik egymást.

A magatartástudományok alapvetése az, hogy bár nem sokan, de léteznek „haszonmaximalizáló számítógépagyú” „Econ” emberek is, ám az emberek döntő 


\section{KÖZELKÉP}

többsége emberi aggyal gondolkodó és döntő „Human”, akiknek a döntései nem véletlenszerűen, hanem szisztematikusan és tendenciózusan térnek el a valószínűségszámítás, a játékelmélet és a közgazdaságtan elméleteinek segítségével kalkulálható „racionális döntésektől” (Kahneman 2013, Thaler 2016). Ezen antropológiai kép különös erejét az adja, hogy a racionális döntésektől való szisztematikus és tendenciózus eltéréseket nem csupán filozófiai spekulációkkal vezették le, hanem a tudomány legerősebb empirikus eszközeivel, a természettudományból átvett kísérleti módszerekkel is igazolták.

Ebben az írásban arról fogok elmélkedni, hogy - bár a Human emberek képzetéből nem születtek olyan nagy és konzisztens teóriák, mint a racionális haszonelvú individuum emberképére épülő olyan paradigmák, mint pl. a klasszikus egyensúlyi közgazdaságtan, vagy a racionális cselekvések és döntések elmélete - de számos vonatkozásban már máig is döntő befolyással bírtak az élet különféle területein, alapvetően abban, hogy miképpen lehet hatni az emberek gondolkodására, döntéseire, magatartására.

Mindenekelőtt olyan területeken, mint a kereskedelmi marketing vagy a politikai kampányok és a propaganda világa, és ezekre adott válaszreakcióként, némiképp károkat enyhítő szándékkal, számos vonatkozásban újragondolásra késztettek olyan közpolitikai területeket, mint a fogyasztóvédelem, az egészség- és környezettudatosság erősítése, vagy a járványokat, éhínségeket enyhítő kríziskezelő programok hatékonyságának a javítása a fejlődő országokban (Barney 1928, Packerd - Cialdini 2009, Thaler - Sunstein 2011, Tracy 2013).

$\mathrm{Az}$ alábbiakban amellett fogok érvelni, hogy bár nem tudom megjósolni azt, miképpen és merre, de az emberi gondolkodásról való képzetek fordulata az emberekkel foglalatoskodó más szakmák területén, így a segítő szakmák, pl. a szociális munka területén is alapvetően új dilemmák felmerüléséhez és új gyakorlatok meghonosodásához fog vezetni. Elmélkedéseimben muszáj vagyok kételyeimet és bizonytalanságaimat előre jelezni. Egyrészt a másokra ható kommunikatív magatartásformák elméletében, tipizálásában, de még olyan, az e dolgozat kulcsfogalmát jelentő fogalom, mint a manipuláció értelmezésében sem rendelkezem komplex és magabiztos, jól megalapozott ismeretekkel, tudásokkal, és ilyen teljes és jó elméleti kereteket nem is ismerek. Másrészt megeshet, hogy ez az én műveletlenségem, de nem nagyon ismerek olyan szakirodalmi munkákat, amelyek a segítő szakmák másokra való hatásának elméleti, gyakorlati és erkölcsi dilemmáit meggyőző eredményekre vezetve boncolgatná. Ennek megfelelően én sem kerek és zárt elmélet vázlatát fogom ismertetni e dolgozatban, hanem inkább nem-tudásom elismerésével, az onnan vezető kiutakat keresgélve vetnék fel olyan szempontokat és kételyeket, amelyek tán közelebb vihetnek a tudáshoz, a helyesről és igazról való meggyőződéshez. Ezt a bizonytalanságot afféle „olvasási instrukcióként” is fontosnak tartom előre jelezni, bár többnyire egyszerűen fogalmazási okokból állító módban fogalmazok, 
www. metszetek.unideb.hu

\section{KÖZELKÉP}

és pontot teszek a mondataim végére, de helyesebb, ha az Olvasó mindenhova egy zárójeles kérdőjelet is odaképzel a mondatvégi pontok után.

\section{A manipuláció hatalma és jelentősége az erős hatásokban}

Amikor hatásról beszélek, akkor hatalomról, hatalmi befolyásról beszélek. Nem a hétköznapi, a „kiszolgáltatottsággal” rokonítható értelemben, hanem Max Weber klasszikus definíciója értelmében. A hatalom az az emberi képesség, amely másokat akár saját „eredeti szándékuktól” eltérő döntésekre, cselekvésük vagy gondolkodásuk megváltoztatására késztet. Ebben a hétköznapitól eltérő értelemben a hatalom a másokra való hatások által „múködik”, így érvényesül.

A modernitás racionális és haszonelvű hagyománya kétféle, az emberi magatartást és gondolkodást befolyásoló hatást ismer.

Az egyik az egy „jó” hatás, az emberek észérvekkel meggyőzése mindarról, ami igaz és helyes. Ehhez a „jó" hatáshoz kell feltételeznie azt a szabad individuumot, akire nem hatnak külső kényszerek, aki benső meggyőződésén és belátásán kívül más, külső hatásoknak nincsen kitéve. Ennyiben a helyesről és igazról való meggyőzés bár "hatás”, de nem feltétlenül hatalom: az igazról és helyesről való meggyőződés az érvek hatására „belsővé válik”, és így nem a cselekvő szándéka, akarata, döntése ellenében, nem kényszerítő erővel hat a hatalom.

Az észérvekre alapuló racionális meggyőzés is lehet tévedés, sőt, akár hazugság is, de az okfejtés alapjául szolgáló tények igaz vagy hamis volta legalábbis elvileg megítélhető, és a következtetések logikája, a logikai következmény helyessége is rekonstruálható, megítélhető. Ennyiben a racionális (logikus, lépésről lépésre haladó) „lassú gondolkodás” (Kahnemann 2013) lehet megtévesztő vagy hamis - de a rekonstruálhatóság, a ténybeli és logikai ellenőrizhetőség miatt nem tekinthető „manipulációnak” abban az értelemben, ahogyan e gondolatmenetben a fogalmat használom.

A másik az egy „rossz” hatás, a hatalomnak való kitettség, mások akaratának kényszerű elfogadása és követése. A gondolat, az igaz és helyes elvek belátása csak a szabad individuum sajátja lehet, azaz az érdekek követésére akkor tudhat berendezkedni a világ, ha azt a hatalmaktól megszabadítjuk, ha abban a szabad individuumok csak maguk döntenek preferenciáikról, a megszerzendő hasznosságok mibenlétéről és a szerzés útjáról/módjáról (Mill 1980 von Mises 1976, Friedman 1953).

Épp emiatt a racionális haszonelvűség hagyománya nem igazán szeret hatalomról beszélni és gondolkodni, a hatalmi effektusokat szereti figyelmen kívül hagyható zavarnak, tévedésnek, az individuum emberi gyengeségének tekinteni. Sőt, olykor a meritokratikus érdemelvűség védelme érdekében tabusítja is azt, hogy a teljesítmény és érdem mellett a hatalomnak (a hatalom révén mások kényszerű hozzájárulásának) is része lehet az egyéni sikerességekben. A hatalmi kérdés központba 


\section{KÖZELKÉP}

állítása leginkább a „demisztifikáló” kritikai társadalomtudomány sajátja. Ha mégis a racionális és haszonelvű hagyományban szó esik a hatalomról, akkor az is racionális és haszonelvű keretekbe ágyazódik: a hatalomnak való ellenszegülés olyan károkkal, fájdalmakkal vagy szenvedésekkel járhat, amelyeket mérlegelve többnyire mégiscsak jobban megéri elfogadni a hatalom elvárásait, legitimnek tekinteni még a szabad akarattal szemben is a hatalom kényszereit és késztetéseit, mint ellenszegülni a hatalmi elvárásoknak.

Ha a manipuláció jelenségének társadalomelméleti és eszmetörténeti gyökereit akarnám felfejteni, akkor Max Weber hatalomelméletéhez kellene visszanyúlnom (Weber 1968). Weber a hatalom fogalmát különböző környezetben különféle értelemben használja. ${ }^{2}$ Melvin Tumin (1967) az egyik legnépszerúbb amerikai szociológia tankönyvében úgy interpretálja Weber legáltalánosabb hatalomelméletét, hogy Weber kétféle hatalomgyakorlást különböztet meg. Az egyik típust jellemezhetnénk úgy, mint a „dominancia-jellegü" hatalom, mely hatalmi képességnek az a sajátossága, hogy azzal hat másokra, hogy képes kellemetlen, veszteségeket és fájdalmakat okozó szankciókkal sújtani azokat, akik nem követik a hatalom elvárásait. (Weber pl. a legitimitáselméletében kizárólag e dominancia-jellegú hatalom sajátosságait elemzi és tipizálja.)

A másikféle hatalmat (akár Tumint követve) „presztízs-jellegư” hatalomnak írhatjuk le, amely nem a szankciók kilátásba helyezésével készteti a hatalom követését, hanem azzal, hogy a hatalom követése valamiféle anyagi vagy szimbolikus jutalmakkal jár, hogy vonzó, pozitív megerősítést és elismerést vált ki. (Weber dominancia-presztízs megkülönböztetését napjaink divatos evolucionista irányzatai is átvették: a dominancia-jellegű hatalom gyökereit az „alfa-hímek” hatalmának feleltetik meg, a presztízs-jellegủ hatalmat pedig az utánzásra, az utánzás révén való „tanulásnak”, ha úgy tetszik, a „majomkodásra” való késztetéseknek.)

Bár a „presztízs” szó francia eredeti jelentésében valamiféle „szemfényvesztést” jelent, de hatalomelméleti tartalma inkább leíró, és nem normatív, így nem is elítélő. A média vagy a divat „hatalma”, sőt a magas elismertségű szakmák (orvos, tanár, pszichológus, vagy akár a szociális munkás) „presztízse” az efféle hatalmára utal. (Tegyük zárójelbe ezúttal azt, hogy e szakmák intézményes beágyazódottsága az elmúlt évtizedekben szankcionálási képességgel, dominancia-jellegű hatalommal is felruházta őket - ez a szakmák képzeteibe tudatosan nem épült be.)

A segítő szakemberek szerepfelfogása az elmúlt években jelentősen megváltozott (korábban a szakértői szerepek domináltak, mára számos modern irányzat a reflexív, kreatív-konstruktív vagy éppen az eredeti angol/amerikai jelentése szerinti felnőtt barát mentori szerepek követését várja el tőlük), de valamennyi ismert

${ }^{2}$ A különféle értelmezések származhatnak abból, hogy a Gazdaság és Társadalom címmel megjelent nagy összegző múvet Weber halála után, félig kész jegyzeteiből mások szerkesztették egy kötetbe. 


\section{KÖZELKÉP}

szerep e „presztízsre”, presztízs jellegű hatalomra épül. ${ }^{3}$ E társadalmi szereplőket, tudásukat, tapasztalatukat (olykor nemcsak) a maguk szakterületén érdemes mintának, irányadónak, az életvitelt, a döntéseket befolyásoló hatalmi tényezőnek tekinteni, hanem a szélesebb társadalmi környezet is olyanként tekint rájuk, akinek a szava az élet egyéb területein is számít, akinek a befolyását, hatását érdemes, előnyökkel kecsegtető megfogadni.

Ebben az értelemben a presztízs jellegú hatalom, és a vele sok szempontból rokonítható manipulatív befolyás hatalma normatív tartalmában semleges: semmi gond nincsen azzal, ha betegségünk esetén nemcsak az orvos által felírt receptet váltjuk ki, hanem a kúrára és életforma-váltásra vonatkozó intencióit is követjük; semmi gond nincsen azzal, ha a tanár „tud valamit”, amit a diák nem, és ezért vonzónak tartja a tanár által képviselt tudás és képesség megszerzését.

Ugyanakkor a presztízs szemfényvesztés értelme már nemcsak semlegesen írja le és interpretálja egy sajátos hatalmi mechanizmus múködését, de elítélő normatív tartalmat is sejtet, sugall. A presztízs nemcsak a tudás, a tapasztalat, a bölcsesség követését emelheti vonzóvá, hanem olykor ostoba és káros divatok, így fényűző „presztízsfogyasztás” vagy okkult tanok majomkodó követésére is csábíthat. (Így pl. gyakran ezt teszik a reklámok.)

Az emberek közötti viszonyoknak, egymásra gyakorolt hatalmi hatásoknak a meggyőzésre és a dominancia jellegű hatalomra való leegyszerűsítése olykor szándékoltan, máskor csak balesetként, de önmagát vakítja el azon hatásokkal szemben, amelyek nem annyira explicitek, mint a dominancia jellegü hatalom kényszerítő ereje; ám messze nem is a meggyőzés lassú és fáradságos, transzparens és „edukatív” folyamata. A magas presztízsű, elismert teljesítményeik révén követendő, vonzó hatást gyakorló társadalmi szereplők (tudósok, művészek, sportolók, sikeres üzletemberek stb.) mellett számos más vonzást gyakorló „manipulatív hatalom” is befolyásolja az emberek döntéseit. A reklám, a marketing és a politikai kampányok propagandistái, professzionálisan csábító és rábeszélő emberei már elég régóta (mondjuk a nagy gazdasági világválság óta) jól tudják, hogy a szankciókkal fenyegető hatalomgyakorlás lebukásának kockázataitól mentesen a leghatékonyabb hatás nem a lassú, racionális agy meggyőzése, még csak nem is a sikerre, magasan értékelt és jutalmazott teljesítményre vezető magas presztízsű emberek fáradságos és hosszú tanulás révén történő követése, utánzása, vonzása váltja ki hanem a gyors gondolkodásra, érzelmi és zsigeri alapú döntéshozatalra ható „csábítás”, illúziók keltése, mondjuk így, mani-

${ }^{3}$ Ez a hagyomány Bourdieu (2013) fogalmát kölcsönözve: „illúzió”, számos más „társadalmi mezőt” is jellemez: az orvoslás, az oktatás, az irodalom, a művészet vagy a tudomány képviselői szintén szeretik azt hinni magukról, hogy ők kizárólag a presztízs-jellegü hatalmuk révén hatnak az emberekre - pedig e területeken is jelentős hatalmi eltolódások zajlottak le a dominancia-jellegű hatalmi mechanizmusok irányába. 


\section{KÖZELKÉP}

puláció. Ebben az értelemben a manipuláció részben jutalmakkal csábító szemfényvesztő presztízs, de legalább ennyire átverés és félrevezetés is.

Épp emiatt a manipuláció kifejezés a köznapi nyelvhasználatban egy elítélő, valamiféle alantasságra utaló kifejezés, amely alapvetően a befolyásolás céljára és tartalmára utal: valamiféle csalás, átverés, megtévesztés, valamilyen a mások kárára történő csalárd előnyszerzésre törekvés.

A szakirodalmi fogalomhasználathoz hasonlóan én is, a „presztízs-hatalom” egy sajátos „szemfényvesztô” részhalmazaként, negatív minősítő értelemben is használom a manipuláció kifejezést. Ám a negatív minősítő tartalom nem a célokra és a tartalmakra utal - azok akár lehetnek tisztességesek és jó szándékúak is, sőt, akár hasznosak is: nincs abban semmi kivetnivaló, ha a gyerekek a magas presztízsű szakmák elsajátítása érdekében tovább akarnak tanulni, ha erre vonatkozó hatást, befolyást gyakorolnak rájuk.

A negatív minősítés az eszközre, a módszerre vonatkozik: arra, hogy a manipulatív befolyásolás nemhogy nem kínálja fel mérlegelésre a befolyásolása célját és okát, hanem határozottan elhallgatja, hogy mire és hogyan akar hatni; olykor kimondottan más célokat nevez meg a befolyásolása szándékaként, mint ami a valós indíték és szándék. A manipuláció ebben a negatív értelmezésben nem a célokat minősíti, hanem az előadásmód, a performatív nyelvi és magatartási gesztusok, kommunikatív tartalmak „sumákságára”, igazolhatatlanságára, ellenőrizetlenségére, gyakran beláthatatlanságára és átláthatatlanságára utaló kifejezés akar lenni. Amikor bárki ebben az értelemben manipulál, akkor a szándéka lehet becsületes és tisztességes is, de reflexiók és ellenőrzési lehetőség nélkül akar hatni.

E manipulatív befolyásolás egyik és talán legfőbb sajátossága az, hogy hatékony. Mert gyors, a gyors gondolkodásra és döntéshozatalra hat. A hatékony manipulatív hatás nézőpontjából minden lassú, akkurátus, logikus, lépésről lépésre haladó lassú gondolkodásra hatás igyekezete - a körülményesség, az idő felesleges pocsékolása. Ugyanoda sokkal gyorsabban és kevésbé körülményesen is el lehet jutni, sőt, a mondandó melletti érvelés és a tartalom ellenőrizhetősége is megspórolható - erre való a manipuláció (Barneys 1928, Packard 1970, Pratkanis - Aronson 1992, Tracy 2013, Cialdini 2009).

Egy reklám poszternek az alatt a pillantásnyi idő alatt is hatnia kell, ameddig a busz elhalad előtte, a tévéreklám csak akkor megfizethető, ha másodpercek alatt átviszi az üzenetet. Egy Facebook posztban nem érvel az ember, nem interpretálja a gondolatot kifejtő szellemóriás gondolatmenetét - hanem „megmondja a frankót”, vagy még azt sem, hanem csak „emo-jeleket” biggyeszt oda. E hatékony kommunikáció némiképp illeszkedik az elmúlt évtizedek minden tekintetben felgyorsult kommunikatív világához. Ahhoz, amelyben az emberek nem olvasnak sem irodalmi, sem tudományos könyveket, amelyben Jancsó és Antioni filmjei nézhetetlenül lassúak, amelyben fontosabb az azonnali, „real-time” klikk-reakció képessége, és ehhez 


\section{KÖZELKÉP}

a kütyük használatára állandóan rendelkezésre álló „stand-by” üzemmód - mint a kommunikáció tartalma, azok megvitathatósága vagy igazságának mérlegelése. Aki ma hatni akar - annak gyorsnak és azonnal reagálónak kell lennie. A lassú érvek (blablablablablabla) - azok el sem jutnak a célközönséghez ${ }^{4}$ (Cialdini 2009, Tracy 2013).

Másrészt, a manipulatív befolyásolás amiatt is „hatékony”, mert közvetlenül hat döntésekre, cselekvésekre. Annak a belátása, hogy Pitagorasz tétele szerint a derékszögű háromszög befogói hosszának négyzetösszege megegyezik az átfogó hoszszának négyzetével, az a világon semmiféle cselekvésre, döntésre nem mozgósít. A manipulatív hatások azzal, hogy a gyors gondolkodásra hatnak, automatikusan azonnali és gyors cselekvésre, döntésre hatnak. Arra, hogy mit vegyél a boltban, kire szavazz a választáson, hogy támogasd a gyülöletet a nép ellenségei ellen, hogy mit lájkolj és mit rendelj meg egyetlen klikkeléssel az interneten.

Ezek a gyors és cselekvésre motiváló manipulatív befolyásolások különösen termékeny táptalajra találnak akkor, amikor a racionális, lassú gondolkodás feltételei és körülményei teljesen vagy részlegesen hiányoznak, amikor a racionális józan mérlegeléshez hiányzik az idő, a tudás, a józan ész képessége, vagy éppen az alkalma (Mullainathan - Shafir 2014).

Ilyen helyzeteket dramaturgiailag meg lehet rendezni (amikor a bevásárlóközpontban eléd pattan egy ifjú hölgy azzal, hogy ilyen parfümöt csak most, csak neked, és csak most azonnal), de még nagyobb valószínúséggel származhatnak abból, hogy az embernek problémája, hiánya, szüksége van valamire, de nem rendelkezik azzal a tudással, hogy mi mennyire enyhíti a gondját, vagy a könnyen elérheto „lehetőség” választása milyen mellékhatásokkal és következményekkel jár. A kozmetikumokat használó nőknek többnyire semmilyen ismeretük nincsen a termékek hatóanyagáról, alkalmazásuk előnyeiről és hátrányairól - ezért ezek ismertetésével nem sokat bajmolódnak a kozmetikai reklámok. Hatásosabb és hatékonyabb arról meggyőzni a fogyasztókat, hogy „mert megérdemled!”, lehetőleg olyan modellek által susogva, akiknek a bőre képszerűen eléggé vonzó - ha nem is feltétlenül meggyőző az, hogy épp attól a kenceficétől.

Igen tanulságos az, hogy az áthúzott árakkal hivalkodóvá tett akciók leginkább azokat a termékeket kelletik, amelyeket nem szoktunk naponta vásárolni, és nincsen róluk jól kiismert, rutinszerú tudásunk. Kenyeret vagy tejet soha, ágymatracot vagy traffipaxot jelző radarkészüléket, azt mindig csak „akcióznak”. (És persze, már „csak egy hétig", a kedves célközönség ne csak azt érzékelje, hogy nyerhet az akcióval, de gondolja azt is, hogy a nyereség kelleménél sokkal nagyobb mértékben fájdalmas veszteséget okoz magának, ha elmulasztja a remek lehetőséget.)

\footnotetext{
${ }^{4}$ E hatékonyságra törekvés már-már abszurd esete az, amikor a tudomány képviselői is azokat a lehetőségeket keresik, hogy miképpen lehet „tudománytalan eszközökkel” (Facebook kampánnyal, videoklipekkel stb.), érvelés és kifejtés nélkül javítani a tudományos eredmények társadalmi hatását...
} 


\section{KÖZELKÉP}

A világ racionális kiismerhetőségének nehézsége még nagyobb és veszedelmesebb terepet nyitott a politikai populizmusok számára. Nemhogy az igaz, hogy a gazdasági/politikai/társadalmi válságból való kimenet racionális útja nem látszódik, de, még a múltbéli okok és magyarázatok feltárásával is adósunk a tudomány. Ebben a helyzetben tarol a politikai populizmus, amelyik az okok racionális feltárása és az azokat orvosló kidolgozott programok helyett az „America first!” (vagy onnan szolgaian átvéve: „Nekünk Magyarország az első!”) jelszavaival akkor is bizalmat gerjesztő, megnyerő, kellemes érzeteket kelt, hogyha a jelszavaknak a világon semmi értelmük vagy tartalmuk nincsen, ha semmit nem mondanak vagy ígérnek arról, hogy milyen politikát akarnak majd folytatni.

A manipuláció térnyeréséhez kétségkívül hozzájárulnak olyan általános jelenségek, mint a kommunikáció felgyorsulása, a hatékonyság hajhászása a kommunikatív magatartásokban, vagy a világról (gazdaságról, társadalomról) való ismeretekbe és a tudományba vetett bizalom erodálódása. De vannak olyan társadalmi célcsoportok, akik a manipuláció veszélyeinek és kockázatainak különösen kitettek. Ezen csoportok legfontosabb jellemzője az, hogy ideiglenesen (pl. azok, akik bárhol eltévednek) vagy tartós élethelyzetükben bizonytalanságokat élnek meg, különösen azok, akik veszteségek és szűkösségek kilátásait élik meg (Kahneman 2013, Mullainathan Shafir 2014). Rájuk különösen jellemző az, hogy az agyukban minden mást elnyom a bizonytalanságok, szúkösségek félelme miatti „csőlátás”, hogy csak azt látják maguk előtt, ami a szúkösség teremtette csőlátás horizontjába belefér, hogy csak addig és arra terjed ki a figyelmük, ami nyomasztja őket. A bizonytalanságnak és a szúkösség csőlátásának van egy „időbeli” dimenziója is: bármi után kapva kapnak, ami azonnali megerősítést, jutalmat, enyhülést ígér szorongásaikra, minden, ami azonnali, az biztos; míg minden más hosszabb ideig tartó, lépésről lépésre haladó, a problémák okát is orvosló megoldás lehetősége csupán okoskodó és szenteskedő hegyi beszéd, az őket nyomasztó problémáktól való elterelés érzetét keltik bennük. Márpedig az élet problémái általában bonyolultak és csak több lépésben, racionális következetességgel oldhatók meg. Az azonnali és gyors megoldások, a „könnyű álmok” ígérete jellemzően félrevezetés, csalás, manipuláció.

\section{A manipuláció „munkadefiníciója” és kiterjedtsége}

A manipulációról szóló, előző „töprengő” felvetéseimet összegezve a manipuláció fogalmán (vállalva definíciós kísérletem vitathatóságát is) a következőt értem:

1. Olyan kommunikatív magatartás, amely nem információt közöl, nem érvekkel győz meg, hanem egyéb eszközökkel igyekszik hatást gyakorolni mások (saját) döntéseire, cselekvéseire, gondolkodására.

2. A manipuláció valamilyen eseti döntési helyzetre vonatkozó befolyásolás. Nem tekinthető manipulációnak az, amikor berögzült, tartósan létező nem-racio- 


\section{KÖZELKÉP}

nális hagyomány (kultúra, erkölcs, hit, vallás) vagy az ilyenekre „tisztességesként", helyesként, követendőként való hatnak ez emberek döntésére, magatartására, gondolkodására (Fél - Hofer é. n., Bowles 2016).

3. Ezek az egyéb hatásmechanizmusok nem az információ címzettjének józan eszére és belátására hatnak, hanem nem tudatosult indítékokra és motívumokra: érzelmekre, zsigerekre, félelmekre, ösztönökre és más „gyors gondolkodásra".

4. A manipuláció messze nem mindig átverés, csalás vagy más, tudatosan alantas megtévesztés, olykor a manipuláció tartalmi célja lehet tisztességes és jó szándékú is, igyekezhet arra hatni, hogy az emberek hozzanak jobb döntéseket, kerüljenek el veszélyeket és ne okozzanak károkat se maguknak, se másoknak.

5. Ennél annyiban több is mondható, hogy a manipuláció nem feltétlenül tudatos magatartás még annak a részéről sem, aki manipulál. Nem kell feltétlenül tudatában lenni a saját manipulatív törekvésről sem ahhoz, hogy valaki „zsigerileg", végiggondolatlanul csábítson, elismerését és elragadtatását, vagy éppen neheztelését és indulatos dühét kommunikálja - annak ellenére, hogy az efféle kommunikatív magatartások is manipulatívan befolyásolnak másokat. Intézmények kommunikatív magatartásában, ahol az intézmények nevében megjelenő üzenetek egyeztetett, megtárgyalt formában kerülnek ki - a manipulációt tekinthetjük tudatos cselekvésnek. (Ilyenek pl. a politikai vagy marketing kampányok.) A manipuláció ilyenkor vagy a közlő céljait illetően akarja megtéveszteni célközönségét (milyen cselekvést, gondolatot próbál meg előhozni belőlük?), vagy, bár akár be is vallja a célját (vásárolj nálam, szavazz rám stb.), de elhallgatja azt, hogy milyen eszközökkel, mivel akarja elérni a kívánt hatást.

6. A manipuláció normatív meg- és elítélése ennyiben nem a szándékok tartalmára vonatkozik, noha a csalók, szemfényvesztők a mások megtévesztéséhez és átveréséhez gyakorta szándékosan és célzatosan, alantasan alkalmazzák a manipuláció eszközeit. Ám a manipuláció köre ennél szélesebb. A manipuláció normatív megítélése tehát nem annak céljára, hanem az előadásmódjára vonatkozik: úgy akar hatni másokra, hogy nem kínálja fel a manipulatív „,üzenetek” józan mérlegelésének és értékelésének lehetőségét; olyannyira, hogy ezeket gyakorta még maguk a manipulálók sem teszik meg saját maguknak sem akkor, amikor éppen manipulálnak. A manipulatív hatás nem ellenőrizhető, nem átlátható, nem indokolja vagy igazolja sem a célja értelmét és védhetőségét, sem a javasolt eszközöknek a (nem tisztázott) célokhoz vezető adekvátságát.

7. A manipuláció nemcsak a közvetlen, személyközi kapcsolatokban jelent „kontrollálatlan befolyást" a másikra, hanem kollektív befolyásolásként is jellemzően kivonja magát a közösségi kontrollok alól: nem vonatkoznák rájuk a demokratikus jogállami tiltások; a piaci (pl. pénz- vagy médiapiaci) önszabályozó fékek és egyensúlyok, vagy éppen szakmák tanult professzionális és etikai normái sem. 


\section{KÖZELKÉP}

8. Végül, az emberi életnek vannak olyan területei és szituációi, ahol a manipuláció nemhogy elfogadott, de a manipulatív hatás nem is váltható ki semmilyen észérvvel vagy meggyőzéssel. Mondjuk az, hogy valaki kacér, csábító, a vonzalmát nem racionális meggyőzéssel fejezi ki - az eléggé magától értetődő, természetes emberi viselkedésnek kell elkönyvelnünk. Ilyen helyzetben az ellenkezője, a „rádumálás” lenne mesterkélt, természetellenes - mi több, szánalmas.

9. Másfelől viszont, mindazt, amit szakszerűnek, professzionálisnak tartunk a világban, az valamilyen módon olyan ténykedéseket és ráhatásokat jelent, amelyek a megtett lépéseket oknak tekintve rutinszerúen, bizonyíthatóan előállítják okozatként a remélt kimeneteket. Sőt, ehhez azt is hozzágondoljuk, hogy a profi szakszerű lépései, beavatkozásai, azok leválaszthatóak a személyiségétől, hogy e lépések, beavatkozások, ráhatások emiatt taníthatóak vagy szabályozhatóak. Ezek a szakszerű kommunikatív módszerek az esetek túlnyomó többségében a józan észre, a meggyőzésre, a logikailag kikövetkeztethető kimenetekre és eredményekre irányulnak, bár, elvileg és a gyakorlatban sem zárható ki az sem, hogy valaki „szakszerűen” és „bizonyítékalapúan” manipuláljon. (Ennyiben: nem tudom jól elhatárolni egymástól az egymás befolyásolására szükségszerűen manipulatív befolyásolására törekvő, „érzelmi” kommunikatív szituációit azoktól a helyzetektől, amelyben ezt a fajta manipulációt negatívan értékelem.)

Azt talán már fentebb is érzékeltettem, hogy a manipulációnak a társadalmi, politikai és gazdasági életben való jelenléte sokkal elterjedtebb, általánosabb és mélyebben ható annál, mint amennyire a közgondolkodásban a becstelen csalásokkal szinonim manipuláció jelentéstartalmából következne.

Társadalmi méretekben a manipulációnak széles teret nyit a világ elbizonytalanodása, érthetetlensége, a kommunikáció felgyorsulása és digitális terekbe történt áttétele, az informális beszélgetések ritkulása, a tudományos eredmények követhetetlensége, a sci-fitől való megkülönböztethetetlensége (Bookstaber 2017, Bowles 2016). A válság e kiismerhetetlen bizonytalanságokat egyértelműen veszteségekbe és szúkösségekbe is fordította. A fejlett világ felső tizedének jövedelmi és vagyoni „elszaladása” a középrétegek és a társadalom többségének relatív veszteségeit, lecsúszását is jelenti - nem csupán jövedelemben és vagyonban, hanem pl. az élettel való elégedettségben is. Ezt a bizonytalanságot csak fokozza az a szorongás, hogy a robotika és a mesterséges intelligenciák térnyerése mellett az emberek (a felső középrétegektől lefelé, mindenki) nem csupán munkájukat, jólétüket vagy gyerekeik jobb életre való kilátásait, hanem társadalmi státuszukat és jelentőségüket is elveszíthetik. Mindez különösen élesen jelentkezik a társadalmi közép lecsúszástól (szegénységtől, társadalmi kirekesztettségtől) rettegő hányadában, amely réteg jó okkal irtózik attól a gondolattól, hogy számára csak a jóléti állam és a szociálpolitika teremtheti meg megélhetését és társadalmi státuszát. Mindez létszámban és a prob- 


\section{KÖZELKÉP}

lémák természetében is jelentős „többletnyomást” teremt a segítő szakemberek, így a szociális munkások számára is.

A manipuláció elterjedése nem csupán szociológiai kategóriák szerint igen kiterjedt, hanem az élet színtereit vizsgálva is. Az ember saját maga manipulálásának igyekezetével szembesül az utcán, a tévében, a reklámokban, de még a hírekben és tájékozódásában is. (Itt csupán a "manipulációs jéghegy csúcsa” az, amit a fake news-ok, az explicit hazugságok jelentenek.)

Manipuláltak vagyunk akkor, amikor belépünk egy boltba (ahol szemmagasságba, könnyen elérhető helyre azt teszik, amit ők ránk akarnak sózni, a saját preferenciáinknak megfelelő áruért hajlongani vagy nyújtózkodni kell; hogy az élelmiszerboltban minden vásárló friss pékárut is akar venni, emiatt a pékárút mindig a bejárattól legtávolabbi helyre rakják ki, hogy közben a gondolák között bóklászva csábuljon el a kedves vendég másra is, mint amit venni akart stb.) (Thaler - Sunstein 2011).

Manipuláltak vagyunk akkor, amikor telefont vagy biztosítást veszünk (megvenni egy perc alatt bármit meg lehet - lemondani, vagy a hűségperiódus utáni megdrágult csomagot módosítani, hát az hetekig tartó procedúra). Manipuláltak vagyunk akkor, amikor programot frissítünk vagy alkalmazást töltünk le a számítógépünkre vagy az okostelefonunkra (a fene sem akar válogatni a különféle letöltési opciók között, senki nem választja azt, hogy magának beállítja azt, amire szüksége van - kényelmesebb nem dönteni, és az alap, a „default” opciót választani, amivel mindent letöltünk, amit ők akarnak), és, hát manipuláltak vagyunk azzal, ahogyan a Google vagy a Facebook helyettünk válogat az információk között, ahogy rangsorokba rendezi a keresésünkre adott válaszlehetőségeket.

Folytathatnám, de nem folytatom a sort. A manipuláció olyannyira elterjedt, hogy mára már a közgazdasági elméletek megreformálásába is többen be akarják építeni a félrevezetés és manipuláció hatásait. A manipulatív, pl. státuszfogyasztást is jelentő termékeknek az árához a láthatatlan kéz által diktált piaci árakon felül hozzá kell rendelnünk mindenféle extra-jövedelmet és árnövekedést eredményező járadékokat is. A két közgazdasági Nobel-díjas, George Akerlof és Robert Shiller a piacok normál múködéséhez tartozónak tekintik az elcsábítható, lökött vásárlók levadászását (könyvük magyar címe: Balekhalászat), és képszerűen azt mondják, hogy az árakat meghatározó „láthatatlan kéz” mellé oda kell képzelnünk a vásárló vállán ülő „láthatatlan majmot" is, aki nem érvekre hallgat, hanem meggondolatlanul és felelőtlenül utánakapkod minden csábításnak (mint a kismajom a banán vagy mogyoró után) (Akerlof - Shiller 2015).

Késő modern világunk tehát mintha mindenkit, mindenhol manipulálni igyekezne. Na és a segítő szakmák? 


\section{KÖZELKÉP}

\section{Szabad-e manipulálniuk a segítetteket a segítő szakembereknek?}

Az eddigiekben tulajdonképpen kivonatolva és értelmezve a „leckét mondtam fel” azzal a céllal, hogy az alapokat rakhassam le fóbb mondandómhoz, és megpróbáljak válaszolni a főbb kérdésekre. Vagy, sokkal inkább: problémákat felvetni, vitát provokálni egy olyan kérdésről, amelyekről a segítő szakmák irodalma annak ellenére nem nagyon foglalkozott, hogy maga a kérdés az elmúlt évtizedekben a világ értelmezésének egy vezető problémájává vált. A felvetéseim ennek megfelelően nem lesznek egyszerűek és könnyen megválaszolhatóak - annak ellenére, hogy szerintem (remélem) eléggé fontosak.

Ha a kérdést a címben jelzett igen leegyszerűsített formában tesszük fel, akkor erre vagy igennel, vagy nemmel lehet csak válaszolni, és van, aki inkább így, és van, aki inkább úgy válaszolna rá - ha expliciten nekik szegeznénk a kérdést.

A hagyományos, racionális haszonelvűség alapjain állók (ismét: nemcsak a tradicionális „szakértői szerepfelfogást vallók, hanem a modern irányzatok képviselői is) még a segítő szakmákban is inkább nemleges választ adnának. E válaszban követnék a manipuláció köznapi meg- és elítélését, és a fogalomról leginkább Thomas Mann Cippollájára asszociálnának a Márió és a varázslóból: a segítő szakember, ha manipulál, akkor alantasságok előhozatala érdekében, maga is alantasan manipulál - amit nem lenne szabad tennie.

Amikor a szociális munka alapelve a „képessé tevés”, akkor ez az elv, bár nem kimondva, de a józan ész alapján képessé tevés legfőbb elvének céljára, érvényesítésére utal. Arra, hogy a kliensnek a józan esze és ítélőképessége alapján kell mérlegelnie érdekeit (vagy a gyermeke, családja legjobb, legfőbb érdekeit), és érdekei érvényesítésének alárendelten kell magának eldöntenie teendőit. Ebben az ethoszban nemhogy megengedett, de elvárt az ügyfélre gyakorolt józan, racionális meggyőző és akár didaktikusan a saját érdekekre ráismertető, rávezető hatás; sőt, némiképp ennek a hatásnak az elérése maga a „képessé tevő” segítő munka lényege. Ez az eszmény a szociális munkás-képzés fő vonulata, és ugyancsak ennek az eszménynek való megfelelés erkölcsi normáit fejti ki a Szociális Munka Etikai Kódexe is.

Ritka kivételnek tekintve azonban az ügyfél szabad akaratától független, a Max Weber-i értelemben akár azzal ellentétes cselekvésre rávevő, rákényszerítő hatalomgyakorlás is megengedett a szociális munkásoktól. A presztízs jellegű hatalmi hatás különösebb korlátok nélkül is, de a dominancia jellegü hatalomgyakorlás csak akkor, ha ezt a hatalomgyakorlást világosan átlátható formában és keretekben gyakorolják. Ilyen keretet jelöl ki az, ha szociális munkásokat a legitim állami hatalom- és erőszakgyakorlás intézményei alkalmazzák: ha a rendőrség állományában vannak (és pl. gyermek- és ifjúságvédelmi vagy drog-területen dolgoznak), ha olyan hatóságok alkalmazzák őket, mint a gyámhatóság vagy különféle munkaügyi hatóságok, hivatalok. Ilyen esetekben mindenki számára világos a képlet: ők akkor is a többségi társadalom és a hatalom érdekei nevében lépnek fel, és akkor is az „erő”, a fenyegetés, 


\section{KÖZELKÉP}

a szankciók alkalmazása és kilátásba helyezésének dominancia-hatását gyakorolják hatalomként, ha eközben (különösen a problémák érzékelése és feltárása során) a segítő szakmákban tanult „racionális” készségeiket, tudásaikat is hasznosítják.

Ennél nehezebb és bonyolultabb az a ma egyre általánosabb probléma, hogy olykor a szociális munkások hivatali és jogi előírásai (ideértve még olyan lágyabb késztetéseket is, mint az „indikátorok teljesítése”) még akkor is elvárják a nyers, szankciókkal fenyegető hatalomgyakorlás adminisztratív és regulázó feladatainak betöltését, ha az illető szociális munkás segítő munkakörben dolgozik. A manipuláció elvetésének elve azonban ezekre az esetekre is vonatkozik, és a fenti átláthatósági elv érvényesítését várja el: amikor a szociális munkás adminisztratív vagy „rendőri” hatalmi funkciót tölt be a kliensével való kapcsolatban, akkor elvárt tőle az, hogy a rá vonatkozó jogi és szervezeti előírásokat nyíltan tárja fel a kliensének, és következetesen ebben a szerepben érintkezzen vele. Az a „mutyizó-bratyizó” szociális munkás magatartás, amelyik azt mímeli, mintha a szociális munkás hatására a kliens a saját érdekeinek megfelelően viselkedne, ám valójában az tőle elvárt magatartás nem az o, hanem a hatalom (és az adott helyzetben őt képviselő szociális munkás) érdekeit követi - az maga a szakmailag és erkölcsileg megvetett, elutasított manipuláció.

Más következtetésre juthatunk akkor, ha a manipuláció mechanizmusait feltáró újabb közgazdasági irodalmat olvassuk. A Nobel-díjas Thaler szerzőtársával, a jogász (később az Obama adminisztráció fogyasztóvédelmi főnöke) Cass Sunsteinnel a válság alatt írt könyvüknek már a címében is semlegesíteni igyekeztek a manipuláció fogalmát azzal, hogy a magyarra lefordíthatatlan (kb. könyökkel oldalba böködés) „Nudge” címet adták könyvüknek (Thaler - Sunstein 2011). Ezt a semlegesítő, és ezzel megengedő törekvést átvette tőlük a Világbank (amely a 2015 évi évkönyvét a magatartástudományi hatásoknak a Bank programjaiban játszott szerepének elemzésére szánta), vagy a Világbankon kívül más nemzetközi szervezetek fejlesztési programjait elemző Esther Duflo és Abhijit Banerjee magyarul is olvasható könyve, A szegények gazdasága (Banerjee - Duflo 2016).

Az ő érvelésük részben arra épül, hogy bármit is teszünk, bármilyen elvárást, gondolatot, üzenetet fejezünk ki másokkal szemben, még ha mondandónknak és céljainknak racionálisan ellenőrizhetők és beláthatók az alapjai, de pusztán azzal, ahogyan azt üzenjük, kommunikáljuk, azzal már a meggyőzésen kívüli hatás-eszközökkel is élünk, azzal már manipulálunk.

Manipuláció az, hogy hány választási lehetőséget kínálunk fel (sok opció közül nehéz választani, kevesebből könnyebb); ahogyan a választási lehetőségeket sorrendbe rakjuk; hogy mi az, amit külön megjegyzés nélkül „alapbeállításnak” teszünk, és milyen más lehetőség választásához kell még valami extra, pl. kis kockákba x-et tennünk; és pláne, hogy mely x-ek magyarázatai vannak a lap alján apróbetűsen szedve; hogy hogyan tesszük fel a kérdést és hova helyezzük el azokat a tárgyakat, amelyek közül választani lehet. Minden hatás gyakorlására törekvő tettnek, gesztus- 


\section{KÖZELKÉP}

nak van valamiféle érzelmekre, zsigerekre, feszültségek gerjesztésére vagy azokat levezető kényelmességekre gyakorolt, minimum „a racionális választást befolyásoló mellékhatása”, oldalba böködő „nudge” nógatása - tehát értelmetlen és felesleges erőlködés azon küzdeni, hogy bárhol, bármiben kiiktathassuk a manipulatív hatásokat. Ennyiben, ha nekik címeznénk a címben feltett kérdést, az ő válaszuk az lenne, hogy persze, természetesen a segítő szakemberek is manipulálják a segítetteket, ha érintkezésben, kommunikatív viszonyban állnak velük, így nem is lehetne ezt megtiltani. Szabad manipulálni.

Bármit is írnak a szociális munka tanai és kódexei - azok mondandójának ellenére is, kimondatlanul, de hasonló konklúziókra jutott az elmúlt években a hazai szociális munka gyakorlata is: nemhogy szabad, de olykor muszáj is manipulálni az ügyfeleket.

Ennek egyik, és legáltalánosabb oka a túlterheltség, egyszerúen az, hogy túl sok ügyfele van egy szociális munkásnak, akikről borzasztó mennyiségű időt köt le az ügyeik adminisztratív elkönyvelése - így végül hihetetlenül kevés idő jut egy kliensre, ügyre, találkozási alkalomra. Ha pedig kevés az idő, akkor gyorsan kell bármit produkálni, amihez nincs idő az élethelyzetek akkurátus, logikus elemzésére, a lehetséges döntési opciók és azok következményeinek végiggondolására. Még ha jóindulatúan fel is tételeznénk azt, hogy efféle „racionális végigbeszélésre” valamennyi szociális munkás felkészült és képes is lenne - akkor is, a reális időkeretekben az ügyfelek gyors gondolkodására, zsigeri és érzelmi alapú döntéshozatalára (gyakorta a beleegyezésük elnyerésére) van csak mód: reálisan, a gyakorlatban muszáj manipulálni őket. És különben is, miért is kellene épp a szociális munkásnak lemondania a gyors, hatékony és erős hatások gyakorlásáról, ha részben mindenki más is élhet ezekkel; részben a szociális munkás dolga is az, hogy hasson, befolyásolja a kliensek döntéseit, magatartásukat.

Ugyanerre a konklúzióra vezet az, ha figyelembe vesszük, hogy az ügyfelek egy jelentős hányada nem, vagy csak korlátozottan képes a dolgok józan, racionális végiggondolására. Az értelmi fogyatékosokkal végzett szociális munka szinte kizárólag manipulatív hatásokra épít, de hasonló mondható el demens öregekről, súlyosan szerfüggő, „eszét elitta” alkoholistákról, de olykor a súlyosan felzaklatott lelkiállapotú, kétségbeesett, csőlátásba szorult emberekről is - akik olykor az ügyek és ügyfelek jelentős hányadát teszik ki.

Ehhez hasonlatos az, hogy számos, még racionális kognitív képességeikben erős, „megvan a magához való esze” ügyfél gondja is abból fakad, hogy „elborult az agya”. Hogy e zaklatottságában elveszítette józan ítélőképességét, mondjuk, a mások elleni indulat, gyülölet és bosszú fontosabb cél számára, mint a saját problémáinak a megoldása (vagy legalábbis azt hiszi, hogy ez a gond és ez a „megoldás”). Letagadhatatlanul vannak ügyfelek, akiknek nem lehet a józan eszére hatni, akiket lehetetlen meggyőzni álláspontja helytelenségéről. 


\section{KÖZELKÉP}

Azt, akit rasszista gyűlölete arra vezet, hogy minden gondjáért a cigányokat tegye meg bűnbakká, ôt racionális érvekkel meggyőzni nézete helytelenségéről nagyjából annyi eséllyel kecsegtet, mint egy Fradi ultrát racionális érvekkel meggyőzni arról, hogy ezen túl inkább drukkoljon az MTK-nak. A rasszista hevületek, elvakult dühök, gyűlöletek, indulatok leszerelésére nincsenek racionális eszközök és módszerek kizárólag manipulatív hatásokkal lehet ezen enyhíteni.

Végül, a szociális munkás manipulációkra való felhatalmazásának érzetét olykor nagyban erősíti az a gyakori helyzet is, hogy maga az ügyfél is manipulálni igyekszik: nem a valódi, érdemi problémák feltárásában akar együttműködni, hanem előnyöket, forrásokat, javakat akar megszerezni a szociális munkás segítségével, akár annak manipulálására is kísérletet téve. Ilyen esetekben sokan „felmentve” érzik magukat a manipulációval szemben - legalábbis az ügyfél manipulatív törekvésének letörésében.

Szóval, államvizsgán a szociális munkások felmondják a tananyagot és még az Etikai Kódexet is arról, hogy nem szép dolog manipulálni - azután meg a napi munkájukban gond nélkül, rutinszerűen, mindennapos praktikaként is: manipulálnak. Olykor szándékosan és célzatosan, máskor meg maguk sem érzékelik még saját ténykedésük, mondandójuk manipulatív természetét.

Nos, a helyzet tehát bonyolultabb, a kérdésre legföljebb manipulatív megtévesztéssel lehet igen vagy nem választ kicsiholni. Az élet általában bonyolult kérdéseket vet fel - amire a racionális, nem populista, nem manipulatív válaszok is csak bonyolultabbak lehetnek.

\section{Ami a szakma racionális múvelése, de nem manipuláció, még ha annak is tünhet}

A szociális munkás ezernyiféle kliens ezernyi fajta problémájával találkozik munkája során, és e problémák megoldásához vagy enyhítéséhez nem lehet egyszerű receptkönyveket összeállítani. Különösen lehetetlen a „képessé tevés” egyszerű receptjeit összegyüjteni. (Pl. ezért kell ezt a szakmát felsőfokú képzésben tanítani, a receptek mechanikus követése, az „betanított munka”.)

Ha azonban ki kellene emelni egyetlen olyan közös, csaknem minden esetben felmerülő feladatot, akkor azt abban foglalhatnánk össze, hogy a szociális munkás ügyfele (ha nem küldik, ha magától teszi, akkor) azért fordul segítségért, mert egyedül nem tartja képesnek magát a problémáján való úrrá levésre. Ennek a banális körülménynek is van egy közös sajátossága: az ügyfelek az átélt drámák, traumák és kudarcok nyomán elveszítik azt az önbecsülésüket és önbizalmukat, hogy ők maguk, segítség nélkül is képesek lennének megoldani az előttük álló próbatételeket, feladatokat. Ezért, bár nem feltétlenül szokás kellő súlyt helyezni erre, de szinte valamennyi szociális munka helyzetben az a képessé tevés legfontosabb megoldandó 


\section{KÖZELKÉP}

feladata, hogy segíteni kell a kliensnek abban, hogyan nyerje vissza önbizalmát, önbecsülését, a magában való hitét. Ha ez a fázis kimarad, akkor minden más, akár részlegesen sikerre is vezető beavatkozás nem képes hozzájárulni a „képessé tevés” alapvető céljainak eléréséhez. (Ez különben a vonatkozó szakirodalom szerint a manipuláció egyik komoly korlátja is: az embereket rá lehet venni arra, hogy másképp döntsenek és cselekedjenek, ám a manipuláció nem alkalmas arra, hogy megváltoztassa a manipulált (pl. ügyfél) világlátását, gondolkodásmódját, habitusát vagy kultúráját.)

Természetesen, az önbecsülés és önbizalom elnyeréséhez is meg lehet próbálni manipulatív eszközökkel, álszent hízelgéssel, negédes bájolgással vagy hazug felértékeléssel is eljutni, ám ezek nem szoktak túl sikeres magatartások lenni, sőt, ha az ügyfél érzékeli, hogy segítője átveri, akkor csak mélyítik a megoldandó gondokat, tovább erodálják a negatív önképeket. Az igazi szakmai feladat a valódi önértékelések és önbecsülések felépítése. Amihez sikerekre, a sikerek megélésére, ehhez a megtett lépések elismerésére és bármiféle „jutalmazására” van szükség.

A mondandóm elég primitív e szempontból: ahogyan minden építkezés, úgy az önbecsülés és önbizalom „felépítése” is csak lépésről lépésre, szintről szintre, szekvenciálisan haladhat. Innen nézve, bár a szociális munkástól eredményeket, megoldásokat várnak el - közvetlenül ugyanezt nem teheti meg a szociális munkás az ügyfelével szemben. A szakma gyakorlásának, művészetének az a lényege, hogy az együttműködések során az elvárt eredményekhez vezető utat úgy kell (és lehet) megtervezni, hogy a közös munka során minden elvárt lépés „megtehető” legyen az ügyfél számára, és minden megtett lépést proaktívan, pozitívan vissza is kell jelezni az ügyfél számára - épp ettől fog erősödni önbizalma és önbecsülése. A problémákat csak a következetesen és célorientáltan egymást követő, ámde egyesével még megtehető kis lépések nyomán lehet megoldani, és eljutni ahhoz, hogy az „alap-problémák" is megoldódjanak, és maga az ügyfél is képes legyen úrrá lenni a gondjain.

A kis lépések, azok egyesével nem feltétlenül jelentenek önmagukban érzékelhető és látványos sikert, de csak így lehet eljutni a problémák megoldására való képessé tételig. Emiatt a szociális munkás szakmájának „nagy trükkje” részben az, hogy hogyan szedi lépésekre a megoldásig vezető hosszabb utat, illetve az a reform-pedagógiában is általános elv, ${ }^{5}$ hogy pozitív visszajelzésekkel megerősítendő kliensi magatartásnak nem a látványos sikereket tekinti, hanem magát a befektetést, a lépések megtételét jutalmazza elismerésével. Nem a munkahely megtalálását és az elhelyezkedést kell a szociális munkásnak értékelnie a munkát keresők esetében, hanem azt, ha az ügyfél tájékozódik a munkaerőpiacon és befektetéseket tesz a megfelelő munka megtalálásáért (milyen álláslehetőség létezik, milyen bérezéssel és

${ }^{5}$ Az olvasási kompetenciák javításáról szóló, mára már közhely az, hogy nem a jobb tanulmányi vagy kompetencia-eredményeket kell jutalmazni (ezek semmilyen eredményre nem vezetnek), hanem azt, ha a gyerekek olvasnak. 


\section{KÖZELKÉP}

munkafeltételekkel, járjon utána, hogy melyik tetszene neki, mi felelne meg számára; keressen, hajtson fel volt osztálytársakat és más távoli ismerősöket, akik hasonló munkahelyen dolgoznak, kérdezze meg őket, arról is, hogy tudnának-e segíteni ott munkát találni, stb.).

Ez a fajta, a teljes segítő folyamatot analitikusan, az egymásra épülő, megtehető lépésekre bontása, a lépések megtételére való rábírás, a befektetések értékelése szakmai trükk, „kunszt”, nem a „tisztán érvelő meggyőzés”, de annak ellenére sem lehet manipulációnak tekinteni, hogy bizonyos mozzanataiban (az azonnali visszajelzés és jutalmazás elemében) kimutathatóak rokonságai manipulatívnak tartható ráhatásokkal is (Banerjee - Duflo 2016).

Sőt, az akkurátus, logikusan egymásra épülő lépések során és nyomán megoldást kereső gondolkodás és magatartás, az maga a racionalitás.

Amit annál kevésbé lehet manipulációnak nevezni, minél inkább a szakma, a szakmai közösség által néven nevezett beavatkozások (pl. protokollok) tudatosan és legitimen elfogadott, elismert „szakmai kunsztok”, tanult és tanítható, ugyanakkor a maga korlátai között ellenőrzött és kontrollált ráhatások befolyásolják az ügyfeleket.

\section{Mikor és hogyan szabad manipulálni a segítő folyamatban?}

Bár, mint jeleztem, vannak, akiknek a véleménye szerint bármely másokra hatni akaró, másokat befolyásoló igyekezet az - ha a döntési lehetőségek tartalmának felkínálásában nem is, de azzal, ahogyan a lehetőségek fel vannak kínálva - mindenképpen manipulatív. Ennek ellenére segítő szakmai attitűdként én magam nem javasolnám ezt a nagyon megengedő hozzáállást a manipulációhoz.

Kulturális és szakmai hagyományaink, etikai normáink, és különösen a képessé tevés szakmai normája alapján alapnak a józan észre ható meggyőzést, a körülmények és a várható kimenetek racionális mérlegelését, az erre való rávezetést kellene elvárnunk a segítő szakembereknek mások életére, döntésére való hatásgyakorlásának mikéntjeként. Ez alól az elvárás alól az sem adhat felmentést, hogy a szociális segítők legfőbb munkaeszköze a saját személyiségük, amely nyilván azzal a következménnyel is jár, hogy különböző személyiségek különféle modorban, nyelvi és kommunikatív eszközökkel képesek hatni a segítettekre. Józan és értelmes szakmai elvárás az, hogy még az egyéni, személyes ráhatások is mindaddig legyenek racionálisak, szakszerűek, a szakma rutinjai szerint ellenőrizhetően és elkönyvelhetően, a szakma tesztelt normái szerint elfogadottak és eredményesek, ameddig erre mód nyílik. Ebből az alapállásból a manipuláció eszközeinek alkalmazását ritkának, kivételesnek, és azok alkalmazásának szükségességét indokolhatónak muszáj tekintenünk.

Kétségkívül van abban némi önkényesség, ahogyan e ritka és kivételes körülményeket megpróbálom összefoglalni - de e normáknak vannak konszenzuális gyöke- 


\section{KÖZELKÉP}

rei. Sőt, még maguk a manipuláció alkalmazásával engedékenyebb szerzők is, implicit módon számos megszorító körülményt jeleznek arról, hogy mikor lehet nyugodt lelkiismerettel manipulálni.

\section{(a manipuláció ne jelentsen kényszert)}

Sunstein és Thaler, amikor a manipuláció negatív mellékzöngéit semlegesíto „nudge” kifejezést alkalmazzák, akkor saját álláspontjukat a „libertáriánus paternalizmus” kifejezéssel jelzik. Ebben a paternalizmus egyértelmúen a manipulációval szembeni engedékenységüket jelzi, ám ehhez ők elválaszthatatlanul hozzáillesztik a „libertáriánus", szabadságelvű kifejezést is. Ami annyit jelent, hogy bár többnyire megengedik a manipulatív, a racionálistól eltérítő befolyásolást - de ehhez szigorúan hozzáteszik azt, hogy a paternalizmus nem jelenthet kényszert. Nem lehet, nem szabad úgy manipulálni, hatni - hogy a manipulatív nyomással erősített választási lehetőséget kötelező legyen választani (Thaler - Sunstein 2011).

A választási lehetőségeknek nemhogy meghagyása, de felhangosítása nemcsak az amerikai szabadelvűség hagyományából következik, hanem abból a szakmapolitikai meggyőződésből is, amelyben az ügyfelek hatalommal való felruházása, hatalmuk elismerése és tisztelete - az azonos a választás, a döntés lehetőségével. Ha van választási lehetőség a döntés meghozatalakor, akkor a delikvensnek van hatalma, ha nincsenek választási lehetőségek, ha csak egyetlen opció választható, akkor az maga a kényszer. (Ezt a koncepciót nem árt mélyebben értelmeznie annak a sajátos hazai (talán európai) szociális hagyománynak, amely számára a választási lehetőség némiképp „luxus”, amelyben örülnünk kell annak is, ha legalább egyetlen megoldási lehetőség kínálkozik, és nem zavartatja magát attól, hogy az egyetlen lehetőség - az a kényszer. Nagyjából ezen felemás értelmezés általános elterjedtsége miatt tartják sokan álszentnek, sőt giccsnek az „empowerment” fogalmának rituális használatát.)

Ezt a minden helyzetben érvényesítendő választhatósági elvet felnagyítja a manipulatív módszerek alkalmazásának felmerülése: ilyen átláthatatlanul és ellenőrizhetetlenül hatni és befolyásolni képes eszközöket csak akkor megengedett használni, ha a felkínált lehetőség követése nem kötelező, ha az ügyfél dönthet másképp is.

\section{(a manipuláció céljai legyenek „jó célok”)}

Sunstein és Thaler ugyancsak evidensnek tekintik (sőt, már könyvük alcímében is jelzik) azt a követelményt, amely szerint a manipulatív befolyásolás célja csak az lehet, hogy alkalmazásuk után az emberek hozzanak jobb döntéseket - egészségükről, pénzükről, kapcsolataikról, az életükről. 


\section{KÖZELKÉP}

Bár lehetetlen volna tételesen körülírni azt, hogy egy döntés mitől „jobb”, mint a helyette meghozandó más, rosszabb döntések, de afféle „minimum-kritériumként” meghatározhatunk néhány normát arról, hogy mi a jobb döntés.

Minimális kritériuma a jobb döntésnek és az arra való befolyásolásnak az a Hippokratészi esküben gyökerező elv, amely szerint „ne árts!”, azaz a manipulatív befolyásolásnak nemhogy nem lehet olyan hatása, amitől az ügyfél olyan döntést hozhat, amely önmagának vagy környezetének árthatna, hanem pozitív formulában ennél több is kimondható. Nevezetesen az, hogy a manipulatív hatások és befolyások akkor megengedhetőek, ha ezzel az ügyfélt olyan döntésétől lehet eltéríteni, amely árthat önmagának vagy környezetének. Mondhatnám azt is, hogy a manipulációval szemben engedékenyebbek lehetünk, ha annak afféle „krízis-prevenciós” céljai vannak, ha e hatás megóvja az ügyfelet attól, hogy uzsorát vegyen fel, hogy közmű és egyéb adósságai miatt elárverezzék a lakását, hogy a pénzhiány kényszerében kurvának küldje a lányát stb. (Mullainathan - Shafir 2014).

(Szükséges jeleznem, hogy ilyen manipulatív krízis-prevenció nemcsak személyes ráhatással, hanem eszközökkel is lehetséges, ilyen, a család egész életére kiható ártalmat és nagyobb kárt megelőző manipulatív eszköz pl. a kártyás villanyóra.j ${ }^{6}$

A jobb döntésre való ösztökélés, manipulálás egyfajta kritériumát megadhatjuk a haszonelvűség kritériumaival: jobb döntés az, amely fájdalmat és szenvedést csökkent, és az, amely révén az emberek egészségesebbek, okosabbak és gazdagabbak lesznek. Banális kimondani ezt az elvet, ám konkrét helyzetekre adaptálni meglehetősen nehéz és szubjektív - ami miatt kétes is. Hogy egy közismert etikai dilemmával érzékeltessem: nehéz eldönteni azt, hogy mikor, milyen körülmények között megengedhető hazug manipuláció eltagadni a gyógyíthatatlan beteg betegségét. Olykor a hazug manipuláció kegyes, és lehetővé teszi azt, hogy hátralevő életében teljesebb életet élhessen a beteg, máskor meg épp a szembesülés és a realitások eltagadása az, ami még jobban tönkreteheti a még hátralevó életet. Hasonló kételyek szinte valamennyi hasznosság kapcsán felvethetők: nehéz összemérni azt, hogy a manipuláció által nyert hasznosság mikor és mennyivel nagyobb, mint az általa okozott félrevezetés, megtévesztés kára. Ilyen tartós kár lehet a személyes autonómia teljes elveszítése, a segítőtől való teljes függés: az a helyzet, amelyben a kliens elveszíti józan döntésképességét, és csak a segítő manipulatív hatásait követve sikeredik a „felszínen maradni”.

Végül hát a kegyes és akár megengedett manipulációk, félrevezetések körébe sorolhatjuk azokat a hatásokat, amelyek - akár a reálishoz képest jelentősen felülértékelve - megerősítik a kliens státuszát, elismertségét, ezáltal önbecsülését és önbizalmát is. Itt sem árt azonban emlékeztetni arra, hogy a szociálpszichológia eredményei szerint igencsak kétélű fegyver a negatív önértékelésű embereket felülértékelni, hiszen ők gyakran ezt nem hiszik el, hazugságnak vélik az ilyen befolyáso-

${ }^{6}$ Lásd: Krémer 2016. 


\section{KÖZELKÉP}

lási igyekezeteket, gyakran ettől csak még inkább leértékelik önmagukat és a segítőbe vetett bizalmukat is elveszítik.

Bár elvileg a „jó célok”, a jobb döntésekre történő befolyásolás elfogadtathatóvá teszi a manipulatív befolyásolásokat is - de, a gyakorlatban szinte alig lehet bizonyosságot szerezni attól, hogy egy döntés, a tartalma szerint mikor, mitől lesz jobb, és mikor, mivel tud ártani.

Talán egyetlen olyan általánosítható elvet tudhatunk rögzíteni, amely mindig a „jobb döntések” meghozatalát stimulálja, provokálja, és ez az, amikor magát a döntés meghozatalát provokálja a manipuláció, amikor azzal szembesíti az embereket, hogy itt döntési helyzet van, hogy dönteni kellene. A káros, önző, félrevezető manipulatív hatások ugyanis gyakran arra építenek, hogy az emberek nem nagyon szeretnek dönteni, és pláne nem nagyon szeretnek sok lehetőség között választva, bonyolult mérlegelések alapján dönteni. Az emberek többsége nem vált telefonszolgáltatót a hűségperiódus lejártakor, és a kötelező gépjármű-biztosítás lejártakor - akkor sem, ha a régi szolgáltatók jelentősen megemelik eredeti áraikat, aminél sokkal olcsóbb lehetőségek is volnának. Ezeket a „Szokás hatalmából” eredő manipulatív hatásokat jellemzően csak hasonlóan erős manipulatív ráhatásokkal lehet ellensúlyozni: dönteni, választani kell, most és nem később, mert akkor már nem lehet. Hasonló döntési helyzetekkel való szembesítés megengedett és progresszív manipuláció a szociális segítő szakemberek részéről, pl. akkor, ha egy kérvényt most és azonnal ki kell tölteni, ha egy hatósági döntés elleni panaszt és fellebbezést azonnal be kell adni, ha a késedelmi díjat azonnal be kell fizetni - mert, bár a nem-döntésre nagyobb az ügyfelek hajlandósága is, de ez bizonyosan nem igazán jó „döntés” a részükről (Kahneman 2013, Thaler - Sunstein2011, Mullainathan - Shafir 2014).

\section{(a manipuláció céljai legyenek transzparensek,} ellenörizhetöek és legitimek)

Amikor elítélőleg beszélünk arról, hogy a kereskedelmi hálózatok, a biztosítási ügynökök vagy a populista politikusok manipulálják a fogyasztóikat, választóikat, akkor az elítélő minősítésünknek két alapja van:

a) egyrészt az, hogy ők azzal az önző céllal befolyásolnak, hogy az emberek döntései számukra legyenek kedvezőek, a mások döntése az ő előnyeiket és hasznukat gyarapítsa, (és ha ügyesen csinálják - mint pl. a jó manipulatív reklámok - akkor az ügyfél azt fogja hinni, hogy döntése, választása neki hoz hasznokat, és nem az üzenetek feladójának)

b) ehhez eltagadják a tényleges szándékaikat, félrevezetik és átverik azokat, akik döntésétől saját hasznuk gyarapodását várják. 


\section{KÖZELKÉP}

E hatások, a kárt okozó csalás és az önző célok érdekében történő félrevezetés elkerülését a manipulációval szemben engedékenyebb szerzők is fontos követelménynek tartják. Amikor Sunstein és Thaler bármilyen „nudge” hasznos alkalmazása mellett érvel, bár nem hangsúlyosan, de mindig beleillesztik példáikba és leírásaikba azt, hogy becsületesen meg kell mondani mindenkinek (nemcsak az érintett személynek, hanem a nyilvánosságnak is), hogy mi a manipuláció (a „nudge”) célja, mihez képest milyen jobb döntések meghozatalára akarják (akár manipulatívan is) rávenni az érintetteket.

A „nudge” politikai, közpolitikai alkalmazása a legkiterjedtebb formában Cameron miniszterelnöksége alatt vált rendszerré, maga a miniszterelnöki hivatal egy „Nudge-unit-ot” állított fel a Downing Streeten - amúgy, Thaler szakértői tutorkodása mellett. Ezen kormányzati „reform task-force” működésére ugyanazok a politikai mechanizmus-szabályok vonatkoztak, mint bármely másra, mondjuk a nyugdíjreformokat kidolgozó bizottságra. Az általuk javasolt intézkedések célját a neten nyilvánosságra kellett hozni, a neten és különféle rendezvényeken vitára kellett bocsátani, a politikai egyeztetési folyamatokon keresztül kellett vinni - és csak ezek után válhattak a kormányzati politika részévé, eszközévé a manipulatív „nudge”-ok. Bár manipulatívak voltak a befolyások, de a demokratikus elveket követve, maximálisan átláthatók és azokat csak a politikai masinéria által legitimmé, elfogadottá emelésük után lehetett alkalmazni. (Bár a Brexit elsodorta a Nudge-unit-ot, és más manipulatív politikák meghatározóbbá lettek Angliában - de, a „nudge” alapú politikák alapvetései „MINDSPACE” mozaikszóval jelzett formában ma is elérhetőek, a neten is.) (MINDSPACE 2015)

Az átláthatóság és a legitimitás elve más formában, de ugyanilyen erővel érvényesült a Világbank és más nemzetközi szervezetek segélyezési programjainak gyakorlatában. Esetükben a kulcsfogalom a hagyományos formában eldöntött, működtetett és finanszírozott programok hatékonyságának javítása volt. Az, hogy a fertőző betegségek (első sorban a malária) ellen jobb, ha beoltatják a gyerekeket a szülők; hogy jobb, ha szúnyogháló-baldachinokat szerelnek fel éjszakára a gyerekágyak fölé - ez egy transzparens, legitim, a döntési folyamatokon az előírásoknak megfelelően elhatározott cél.

Ha a gyerekek beoltásához az anyákat manipulálják (értsd: korrumpálják, lefizetik) még egy tál lencsével (az oltás távoli és bizonytalan hasznáért cserébe azonnali, biztos és kézzel fogható előnyöket is adnak), akkor az ugrásszerűen javítja az oltási programok hatásosságát. Többen fogják beoltatni a gyereküket, és a program hatékonyságát is javítja a tál lencse, hiszen az egy főre jutó oltási költség legnagyobb része az orvosi személyzet és az eszközök „kivonulása” és díjazása, ehhez képest a tál lencse ára nem tétel.

Mindez nem csupán spekuláció, ezt a nemzetközi szervezetek mérik is, összehasonlítva egymással a tál lencsével kiegészített, és „kontroll-csoportként”, különböző 


\section{KÖZELKÉP}

falvakban, térségekben végrehajtott, lencse nélküli programjaikat (World Bank Report 2015, Banerjee - Duflo 2016).

A transzparencia és legitimitás szükségességét alátámasztó tapasztalatok jellemzően közösségi, politikai szinteken végrehajtott manipulatív beavatkozásokról szólnak. Nem egyértelmű azonban az, hogy miképpen lehet e követelményeket egyes esetek, családok esetében is érvényesíteni.

A transzparencia és legitimitás elnyerésének e szinten van egy alapvető fontosságú előfeltétele. Nevezetesen az, hogy magának a szociális segítőnek kell mindenkinél jobban tisztában lennie azzal, hogy milyen céllal, milyen (akár manipulatív) hatásokkal akarja befolyásolni kliensének döntését. Csak ezen az alapon, e szakmai ténykedés néven nevezett, elkönyvelt és „elszámolt” bemutatása jelentheti a „transzparenciát" és csak ezeknek a felvállalása esetén nyerhető el e hatások és befolyások legitimitása, erkölcsi és szakmai elfogadottsága. Részben a munkaszervezetekben, a főnököktől és a kollégáktól, de még inkább, a szélesebb körű szakmai közösségtől, a hivatás gyakorlóinak mérvadó megítélése által.

\section{(a manipuláció mint akut patologikus tünetek gyógyszere és terápiája)}

A manipulatív hatások normál, helyes használatukban hasonlatosak a fertőzéses, lázas betegségek gyógyszereihez. Bár néhány ritka és kivételesen krónikus állapotban tartósabban is kell élni a manipuláció gyógyszereivel (korábban jeleztem: pl. értelmi fogyatékosok, demensek, vagy idült alkoholisták és szerfüggők stb.), de azok alapvetően csak rövid ideig, és valamilyen értelemben (nem feltétlenül az életveszély értelmében) kritikus állapotokban alkalmazandó. Bár vannak segítői késztetések a manipulatív függés tartós fenntartására (lásd pl. a "helper-szindróma” esetét), de alapvetően a manipulatív befolyásra és hatásra való tartós berendezkedés nemhogy rontja a segítés eredményességét, hanem kimondottan lehetetlenné teszi a képessé tevés szakmai céljainak elérését. (Ebben is olyan a manipuláció, mint a lázcsillapító, az altató vagy az antidepresszáns: rövid és akut betegségek kezeléséhez jól jönnek - a rájuk való tartós berendezkedés komoly károkat okoz nemcsak egészségben, hanem általában, függésben, az életvitelben is.)

Kétségkívül akut szorongásosban, szűkösségekből fakadó csőlátásban és torzult ítélőképesség, önfeladott önbizalomvesztés, talajvesztett elbizonytalanodás, döntésképtelenség, és más, hasonló „akut” állapotokban egyszerűen a korábban is jelzett, még nagyobb bajok elkerülése érdekében, olykor nemhogy szabad, de kell is manipulatív ráhatással élni. Ha valakinek ilyen állapotban egy hivatalos beadványt kell kitöltenie és aláírnia - a szakmájához értő szociális segítő nem adja oda a formanyomtatványt, hogy azt majd otthon ellenőrizze az adatokat, és kitöltve hozza vissza a kliens - mert nagy valószínúséggel soha nem fogja visszahozni. Lehet, hogy nem lesznek teljesen pontosak az adatok, lehet, hogy kényelmetlenül, az asztal sarkán - 


\section{KÖZELKÉP}

de rá kell venni (trükkel, csellel, ármánnyal is), hogy ott azonnal töltse ki a papírt. Ha valaki anyagi megszorultságában az uzsora felvételét fontolgatja - akkor akár nem igaz, nem szükségszerű következmények elrettentésével, elborzasztással, manipulatív horrorok kilátásba helyezésével - de meg kell akadályozni azt (Mullainathan Shafir 2014).

Ám ezeknek a manipulatív hatásoknak nem lehet más a céljuk, mint az ügyfél kizökkentése, kihozatala a torzult tudatállapotokból, a józan ítélőképesség minél hamarabbi visszanyerése. Szerintem ez a „képessé tevés” lényege, ugyanakkor: legdrámaibb és legkritikusabb szakmai fázisa.

(a manipuláció mint a segítő folyamat megengedhetố kezdeti fázisa, amely segíthet eljutni az ügyféllel való racionális diskurzusig és együttmúködésig)

Számos vonatkozásban a fenti „legitim manipulációs helyzetek” afféle összegzése is az a szakmai álláspont, hogy a segítő folyamat elején (a bizalom és a kapcsolat személyes kereteinek megteremtéséhez, a játszmák letöréséhez és kiiktatásához, az együttmüködés kooperatív légkörének a megteremtéséhez stb.) nélkülözhetetlen és kiiktathatatlan az érzelmi alapú, manipulatív hatások alkalmazása is. Átmenetileg, és döntően a racionális, józan észre és meggyőződésre épülő kommunikatív helyzetek és együttműködési feltételek megteremtéséig, épp ennek az érdekében. Amely elvárásban jelen van egy furcsa ellentmondás, hogy ti. maga a manipuláció addig és azért megengedett - hogy túl lehessen lépni azon a fázison, amelyben szükséges manipulálni az ügyfeleket, hogy el lehessen jutni egy „nem-manipulatív”, racionális alapú kooperációig. Ami szinte követhetetlen elv: a sikeresen manipulatív beavatkozás további sikeres manipulatív hatásmechanizmusokra ösztönöz - és nem annak felszámolására.

Fentebbi felvetéseimet nem szentenciának és az igaz és helyes nézetek összefoglalásának szántam. Sokkal inkább problémafelvetésnek, javaslatnak és provokációnak: el kellene töprengeni e felvetéseken.

Mindezt részben azért, mert magam sem vagyok biztos felvetéseim jogosságában és helyességében. Másrészt azért, mert a javaslataim és felvetéseim bizonyos manipulatív segítő magatartásokra vonatkoztathatóak - de másokra nem feltétlenül. Illusztrációnak egy példa erre: jól tudjuk azt, hogy az emberek sokkal jobban hisznek ízes és plasztikus sztoriknak, eseteknek - mint, mondjuk statisztikai gyakoriságokban, megoszlásokban közreadott „objektív tényeknek”; és sokkal jobban lehet rájuk hatni magas presztízsű emberek személyes varázsával, mint az objektív tényekből levont tanulságokkal. Hogy a segítő szakemberek nem nagyon akarnak élni az objektív, szociológiai tények statisztikus leírásaival - ezt mélyen megértem, a statisztikákban az ügyfelek nem bíznak (van is okuk rá), nem is értenek hozzá - 


\section{KÖZELKÉP}

és hát az igazság az, hogy maguk a segítő szakemberek sem. Hogy ezen az alapon lehet-e a szociális munkásnak megnyerő emberek meggyőző erejú manipulatív tantörténeteivel hatniuk (végtére, a vallások nagy könyvei, a Biblia, a Talmud meg a Korán is ezt teszi), ebben nem tudok állást foglalni. Az biztos, hogy veszélyes lenne azt mondani, hogy hát persze: a kivételek, a ritka szerencsések példázatai káros, félrevezethető manipulatív csalás is lehet. Az „objektív” tudományosan megerősített (pl. statisztikai) adatokat az emberek nem értik, nem tudnak belőlük következtetéseket megvonni - ilyenekkel előhozakodni, ennek semmi értelme. Így maradnak az egyéni sztorik, amelyek életszerü, gyakorlatias és manipulatív példáival mégiscsak lehet, hogy szabad is, és kell is élni. De, vissza az elejéhez: azok megtévesztőek, átverősek is lehetnek, amit meg nem kellene támogatni. Tehát, még ha jogosak és megalapozottak is a fenti érveim bizonyos manipulációk alkalmazásának korlátait és feltételeit illetően - abból még nem következik, hogy azok jogosak és helytállóak más fajta manipulatív befolyásokra vonatkoztatva.

\section{A manipulatív hatásokkal és befolyásokkal szembeni védelem és immunizálódás segítése}

A segítő szakemberek ügyfelei számára legfeljebb ritkán leselkedik jelentős veszélyként a segítő szakemberek dilettáns, vagy akár rossz szándékú (mert, ilyen is előfordul) manipulatív gyakorlata. A legsúlyosabb veszély mindaz a lépten-nyomon felbukkanó manipuláció, amelynek fô átverős aktorai és indulatokat, gyưlöleteket és más alantas érzelmeket generáló ártalmas ágensei a piac és a politika szereplői, olykor más hivatalok és közszolgálatok reprezentánsai.

Innen nézvést legalábbis nem az a segítő szakmák legfontosabb kérdése, hogy szabad-e, és, ha igen, akkor mikor, milyen korlátozásokkal és megszorításokkal lehet maguknak manipulálniuk az ügyfeleiket - hanem az, hogy miképpen tudhatnak segítséget nyújtani ahhoz, hogy kevésbé legyenek/lehessenek megvezethetők, átverhetők, ebben az értelemben manipulálhatók. (Mullainathan - Shafir 2014, Thaler - Sunstein 2011).

Töredelmesen meg kell valljam, bármennyire is izgalmas, érdekes, a világ értéséhez és értelmezéséhez sok fontos dologgal hozzájárulónak tartom a magatartástudományok, a magatartási közgazdaságtan újabb eredményeit - azért borzasztó dühös vagyok ezen irányzatra, hogy a manipuláció gazdasági, politikai, társadalmi válságainak tombolása közepette sem tették fel ezt a kérdést, és így nem is nagyon mondanak erről, szinte semmit. Én magam magamra is dühös vagyok, mert viszonylag keveset tudok erről mondani - noha, tán ez fontosabb lenne mindannál, mint amit itt fentebb felvetettem az indokolható, de még több manipulációról. 


\section{KÖZELKÉP}

(időt nyerni...)

Minden józan és racionális gondolat, minden következetes, logikus, az eredményeket visszacsatoló és ellenőrző gondolkodás - az lassú. Ahhoz idő kell. Az, ami gyorsan is megy, az azonnali és „csípőből tüzelő” döntéshozatal, az érzelmi, indulati és zsigeri alapú, másokat manipulálni igyekvő, de ugyanakkor mások manipulációinak kitett döntéshozatal. Amely gondolkodási és döntéshozatali magatartásra való késztetés, hatás, befolyásolás a mai világunk alapvető működésmódja, az élet minden területén, elsősorban a személytelenné vált kommunikáció által dominált területeken: a tévében, a reklámokban, a politikai kinyilatkoztatásokban, az interneten és a közösségi médiában.

Ez a fajta befolyásolás és hatás az, ami erős, ami sokakat elér, ami hatásos és hatékony, ami miatt a modern világok mindenben ezeket a csatornákat, ezeket a hatásokat hajkurásszák, ebbe igyekeznek berántani mindenkit. (Lásd: „aki nincs Facebookon és az Instán, az nem is létezik...")

Ez részben azt jelenti, hogy minden pillanatban, minden médián keresztül, minden döntésünket efféle manipulatív hatások igyekeznek befolyásolni. Némiképp azt is jelenti, hogy a hagyományosan lassú és racionális gondolkodás is áttranszformálódott gyors, ütős, hatékony befolyásolássá. Még a tudományos élet képviselői sem olvasnak hosszú könyveket, nem rekonstruálnak gondolatmeneteket - hanem rákeresnek az adott kulcsszót tartalmazó bekezdésekre, és csak annyit olvasnak el egy publikációból. Az emberek nem olvasnak könyveket, nem bámészkodnak kiállításokon eltöprengve azon, hogy mi is volt a mellbevágó azon a képen - hanem klipeket, képregényeket és a neten megosztott képeket tekerik át, egyiket a másik után. Nem mérlegelik a hírek jelentőségét és igazságát - hanem bedőlnek az elborzasztásra, erős érzelmi hatásokra játszó klikkek és lájkok érzelmi hatásainak, vadásszák a hasonló erős hatásokra játszó bulvár- és fake álhíreket.

De mindez részben azt is jelenti, hogy a lassú, logikus, racionális gondolkodás terei és alkalmai kiürültek, elfogytak, azok léte messze nem természetes - azokat komoly erőfeszítésekkel meg kell teremteni. A manipuláció elleni védelemben és a képessé tevésben segíteni igyekvő szakembernek (minden rá is ható „hatékonysági” követelményeknek és időszorításnak ellenállva is) abban kreatívnak és ügyesnek kell lennie, hogy az ügyfelek időt nyerhessenek. Hogy legyen alkalom és idő eltöprengeni, kételyeket mérlegelni, mindenféle ötleteken elmerengeni, kiszűrni abból a csacsiságokat és megtartani az okosságokat.

Az eltöprengésre, elgondolkodtatásra késztető időnyerésben felnagyul a „segítő beszélgetés" jelentősége. Nemcsak annak nyugodt, lassú hangulatában és modorában, nemcsak abban, hogy a csőlátások horizontján kívül eső, de az élet fontos dolgait jelentő ügyek is bekerüljenek a látókörbe - hanem abban is, hogy a beszélgetés során felmerülő kérdéseknek meg kell ragadniuk az ügyfelet, el kelljen töprengenie 


\section{KÖZELKÉP}

azokon a beszélgetés után is. No meg abban, hogy legyen második beszélgetés is, ahol meg lehet osztani mindazt, amire töprengései során jutott.

Tán bizarr az, amit mondok, de maga a lassúságra, a lassú gondolkodásra való ráhangolás is fontos szakmai sikere lehet a manipulatív hatások ellen védelemben segítséget nyújtani igyekvő szakember számára: akár az is, ha ügyfelét ráveszi egy könyv elolvasására, egy barátokkal való sörözésre, vagy a hétvégi kirándulásra és hosszabb sétára. Ezek eléggé improduktív segítségeknek tűnnek, pedig, ha jól belegondolunk, mi magunk is ilyen helyzetekben szoktunk eltöprengeni, elgondolkodni a magunk és a környezetünk sorsáról.

\section{(kapcsolatokat nyerni...)}

Robert Putnam korszakos jelentőségű könyvében (Bowling Alone) már 2000-ben érzékelte azt az állapotot, hogy miközben minden hírt és információt meg lehet találni az interneten, aközben csak azok képesek szelektálni ebből az információtömegből, csak azok képesek leválogatni azt, hogy „mi is a valódi és értékes hír és információ" - akik ezt másokkal megbeszélik. Számára ez a beszélgetős, egymás gondjaira fogékony, egymás iránt bizalommal viszonyuló, egymásnak is segítőkész társadalmi közeg és környezet a „civil társadalom”. (Ami nagyon más, mint a „civil szervezetek" világa.) (Putnam 2000)

Egykori meglátása ma aktuálisabb és lényegre törőbb, mint hajdanában. Az emberek magányáról, kapcsolathiányáról már régóta tudjuk, hogy az különféle mentális és pszichoszociális ártalmak (így a szerfüggések) forrása, és azt is, hogy a világ dolgait egymással meg nem beszélő emberek tájékozatlanabbak és ostobábbak beszélgetős társaiknál, mi több, még rosszabbul is élnek, pl. munkakeresési gondjaikban sem segítenek az általában legfontosabb segítséget jelentő ismerősök. Ám mára a helyzet annyiban romlott, hogy a magány sokkal „természetesebb” lett attól, hogy a közösségi kapcsolatok természetes alternatívájává váltak a virtuális kapcsolatok; hogy a "társadalmi tőke” (annak akármilyen, a Coleman-Putnam, vagy Bourdieu fogalmainak értelmében) kiválthatónak túnik a lájkokban és klikkekben mért „virtuális társadalmi tőkével”. Nem kívánnám e folyamatok ártalmaiban felidézni a vonatkozó pszichológiai szakirodalmat, de nyilvánvaló és közismert tény az, hogy a manipulációkkal szemben lényegesen sérülékenyebbek a magányos, kapcsolathiányos emberek.

Ezt megállapítva ismét banális következtetést tehetünk a manipuláció elleni immunitást erősítő szakmai segítségekre: rá kell venni az embereket, hogy beszélgessenek egymással. Otthon, a gyerekkel, a rokonokkal és barátokkal, hogy hívják meg egymást egy kávéra vagy egy sörre, hogy találkozzanak másokkal, akár a suli udvarán a sörmeccsen, akár a templomi énekkarban. 


\section{KÖZELKÉP}

Felvetésem, csakúgy, mint a korábbi, túl snassznak, túl banálisnak túnik - talán azért, mert túl természetesnek tartjuk azt, hogy ilyen alkalmak, ilyen élethelyzetek „úgy maguktól is” vannak. De, talán épp e természetesség feltételezése miatt nem árt hangsúlyozni azt, hogy mekkora gond és baj az, amikor ilyenek nincsenek. A magányosságból fakadó bajok és gondok talán legsúlyosabbja az, hogy a magányos emberek látens és virtuális kapcsolataikba, a mesterségességükben és tényleges közösségi megerősítések nélküli identitásaikba, a divatkövetés és státusfogyasztás révén társadalmi csoportokhoz tartozás illúziójába kapaszkodnak - amitől még könnyebben és veszélyesebben manipulálhatóak.

\section{(a manipulációk kiismerése és leleplezése...)}

A pszichológia tudománya (és különösen az analitikus hagyomány) már régóta arra a sémára épül, hogy ha a „sors-szerü”, belül fortyogó lelki történéseknek nevet ad, fogalmakkal leírja, akkor ezzel nemcsak racionálisan elmesélhetővé és értelmezhetővé, hanem kezelhetővé és gyógyíthatóvá is teszi mindazt, ami patologikus. Némiképp hasonló a kritikai szociológia „lebuktató” és demisztifikáló hagyománya is: a társadalmi és hatalmi viszonyok néven nevezése, értelmezése eszközt ad a nem kívánatos társadalmi jelenségek orvoslására is.

Bár szeretném, de nem mondhatom el ezt a manipuláció pszichikus vagy társadalmi jelenségeiről. Egyszerűen nem értjük azokat, nem nevezzük néven azokat, és adekvát fogalmak híján nem is tudunk gondolni túl sokat róluk - még annyit sem, mint amennyit igazából tudhatnánk, ha helyén kezelnénk súlyát, akár kárát, ártalmát. (Amit leginkább tudunk, az az, hogy hogyan és miképpen NEM racionálisan és haszonelvűen döntünk és gondolkodunk (Collins 2015, Kahneman 2013, Thaler 2016). Arról egyelőre kevesebbet, hogy akkor valójában hogyan is?)

Azt hiszem, hogy a segítő szakemberek azzal tehetik a legtöbbet segítettjeik manipuláltsága, manipulálhatósága elleni védelemben, ha jobban ismerik az embert, az emberek és intézmények közötti hatások és befolyások természetét, ezek hatalmának erejét - és egyszerúen rávezetnék, elmesélnék nekik azt, hogy hol hogyan lettek átverve, megvezetve, manipulálva. Ha ezzel, a néven nevezett hatások ellen képessé tudnák tenni ügyfeleiket önmaguk védelmére, a valós lehetőségeik feltárására, értékeik és preferenciáik autonóm követésére, az ehhez szükséges döntések meghozatalára. (Az persze egy másik, de szintén nem lekezelendő súlyú kérdés, hogy maguknak a segítőknek is mennyit használna az, ha ők maguk felfedeznék a rájuk ható manipulációkat, ha értenék az őket befolyásoló hatások mechanizmusait, ami tán ahhoz is alapot adhatna, hogy ők maguk önreflexívebben élhessenek a manipulatív befolyás eszközeivel, hatásaival.)

Úgy vélem, hogy ma mindezen problémák jelentősége nemcsak amiatt jelentősebb, mint korábban - merthogy, a racionális, a józan észnek ellentmondó embe- 


\section{KÖZELKÉP}

ri-döntéshozatali effektusok és az ezeket kihasználó manipuláció jelentőségét csak az elmúlt időszakban fedezte fel és dokumentálta az ember- és társadalomtudomány. Hogy e területen oly súlyosak az elmaradásaink, hogy nemcsak az ügyfelekre, hanem magukra a segítőkre gyakorolt manipulatív befolyásokkal és hatásokkal sem vagyunk tisztában.

Magyarországon különösen azért, mert hosszú ideig a szociális munka nem anynyira a kliensek döntéshozatalára akart hatni, hanem, a legkülönfélébb eszközökkel, többletlehetőségekkel akarta kistafírozni őket: segélyt, szociális ellátást járt ki nekik; projekteket organizálva munkát és elfoglaltságot igyekezett szerezni nekik; olykor felvállalta politikai és érdekképviseletüket, vagy ezek megszervezését; máskor információkat közvetítve és ügynökösködve menedzselték a klienseknek szükséges, nekik járó közszolgálatok (orvos, iskola, hivatalok) elérhetőségét.

Nincs okom ezen - a mondjuk így, inkább „szociálpolitikai”, mint a szó nemzetközi fogalomhasználata szerinti „szociális munka” - hagyományok erkölcsiségének, tisztességességének, vagy akár hatásosságának kétségbe vonására. Pusztán annyit kell szomorúan, afféle válságtünetként regisztrálnom, hogy a hazai szociális munka forrásai, ügynöki, információ-brókeri, közvetítői és ügyfelet menedzselő eszközei és lehetőségei napjaink politikai környezetében kiüresedtek és minimálisra csökkentek.

Ha segíteni akarunk a klienseknek, ügyfeleknek, akkor egyre kevésbé remélhetjük azt, hogy a segítségünk anyagi természetű, jóléti szolgáltatásokhoz jutást segítőek lehetnek - mert ezek ebben az érában kifogytak.

A segítésben, ami megmaradt, az a szociális munkás személyisége, az ügyfelek életére gyakorolt segítő hatása, befolyása, és az ügyfelekben való bizalom: ha a segítők nem feltétlenül, de ők, a maguk világában, jobb döntéseikkel képesek lehetnek kihasználni a rendelkezésükre álló teret, képesek lehetnek elmenni a falakig.

Számomra valami hasonlót jelent a „képessé tevés” szakmai segítő alapfilozófiája.

\section{Irodalom}

Akerlof, G. A. - Shiler, R. J. (2016): Balekhalászat -A manipuláció és az átverés közgazdaságtana. (eredeti: Phising for phools 2015), HVG Könyvek Kiadó, Budapest.

Barneys, E. L. (1928): Manipulating public opinion: the why and the how? American Journal of Psychology, 33/6, 958-971, http://w.truty.org/PDFs/Media/BERNAYS-ManipulatingPublicOpinion.pdf (utolsó letöltés dátuma: 2019. április 15.)

Benerjee, A. - Duflo, E. (2016): A szegények gazdálkodása. Balassi Kiadó, Budapest.

Bookstaber, R. (2017): The End of Theory Financial Crises, the Failure of Economics, and the Sweep of Human Interaction. Princeton University Press. 


\section{KÖZELKÉP}

Bourdieu, P. (2013): A művészet szabályai. Az irodalmi mező genezise és struktúrája. Budapesti Kommunikációs és Üzleti Főiskola, Budapest.

Bowles, S. (2016): The moral economy - Why good incentives are not substitute for good citizens. Yale University Press.

Cialdini, R.B. (2009): A hatás - a befolyásolás pszichológiája. HVG Könyvek Kiadó, Budapest.https://docplayer.hu/158725-Robert-b-cialdini-hatas-a-befolyasolaspszichologiaja.html (utolsó letöltés dátuma: 2019. április 15.) (2015): Please, not an another bias! An evolunatory take on behavioural economics. https://jasoncollins.org/2015/07/30/please-not-another-bias-an-evolutionary-take-on-behavioural-economics/ (utolsó letöltés dátuma: 2019. április 15.)

Fél E. - Hofer T. (1997): Arányok és mértékek a paraszti gazdálkodásban. Balassi Kiadó, Budapest. http://mek.oszk.hu/04900/04950/04950.pdf (utolsó letöltés dátuma: 2019. április 15.)

Festinger, L. (1957): A Theory of Cognitive Dissonance. Stanford University Press.

Friedman, M. (1953): The Methodology of Positive Economics. In: Milton Friedman (ed.): Essays in Positive Economics.. The University of Chicago Press, Chicago.

Halpern, D. (2015): Inside the Nudge Unit - How small changes can make a big difference. WH Allen.

Kahneman, D. - Tversky, A. (1971): Beliefe in the strong law of small numbers. Psychological Bulletin, Vol. 76, No. 2, 105-110. http://stats.org.uk/statistical-inference/TverskyKahneman1971.pdf (utolsó letöltés dátuma: 2019. április 15.)

Kahneman, D. (2013): Gyors és lassú gondolkodás (eredeti: Thinking Fast and Slow, 2011), HVG Könyvek Kiadó, Budapest.

Krémer B. (2016): Csőlátásaink, beszorultságaink, manipuláltságaink - avagy: segítettek, segítés és társadalompolitika új megvilágításban. Esély, 2016/1. http:// www.esely.org/kiadvanyok/2016_1/2016-1_4-1_Kremer_Csolatasaink.pdf (utolsó letöltés dátuma: 2019. április 15.)

Krémer B. (2018): Kísérlet csőlátásaink oldására - További gondolatok a behavioral economics-ról. 2018/2, Munkaügyi Szemle, https://www.munkaugyiszemle.hu/kiserlet-csolatasunk-oldasara-tovabbi-gondolatok-behavioral-economics-rol (utolsó letöltés dátuma: 2019. április 15.) (2018): Tényleg ennyire hülyék lennénk? - Gondolatok a behavioral economics-ról Richard Thaler 2017es közgazdasági Nobel-díja kapcsán, 2018/1 Munkaügyi Szemle, https://www. munkaugyiszemle.hu/tenyleg-ennyire-hulyek-lennenk-gondolatok-behavioral-economics-rol-richard-thaler-2017-es-kozgazdasa (utolsó letöltés dátuma: 2019. április 15.)

Kuhn, T. S. (2000): A tudományos forradalmak szerkezete. (eredeti: 1970), Osiris Könyvtár - Madárfejűek Társasága, Budapest http://lazarus.elte.hu/ zoltorok/ 
www. metszetek.unideb.hu

\section{KÖZELKÉP}

oktat/Kuhn/a_tudomanyos_forradalmak_szerkezete.html (utolsó letöltés dátuma: 2019. április 15.)

Lewis, M. (2017): The Undoing Project - A friendship that changed our mind. W.W. Norton \& Co.

Mill, J. S. (1980): A szabadságról. Magyar Helikon, Budapest.

MINDSPACE Influencing behaviour through public policy, 2010, UK Cabinet Office UK Institute for Government. http://38r8om2xjhhl25mw24492dir.wpengine. netdna-cdn.com/wp-content/uploads/2015/07/MINDSPACE.pdf (utolsó letöltés dátuma: 2019. április 15.)

von Mises, L. (1976): Epistemological Problems of Economics. New York University Press, New York.

Mullainathan, S. - Shafir, E. (2014) (eredeti: 2013): A szűkösség pszichológiája - Miért jelent sokat, amiből kevesebb van? HVG Könyvek Kiadó, Budapest.

Packard, V. (1970) (eredeti: 1957): The Hidden Persuaders. Penguin, London.

Pratkanis, A. R. - Aronson, E. (1992): A rábeszélőgép. AbOvo, Budapest. https:// www.scribd.com/document/57147459/Pratkanis-Aronson-A-rabeszel\%C5\%91gep (Age of Propaganda: The use and abuse of persuasion, 1992) (utolsó letöltés dátuma: 2019. április 15.)

Putnam R. D. (2000): Bowling Alone. Schuster \& Schuster, New York.

Thaler, R. H. (2015): Misbehaving - The making of behavioral economics, 2015, W.W. Norton \& Co.

Thaler, R. H. - Sunstein, C. R. (2011) (eredeti: 2008): Nudge - Jobb döntések egészségről, pénzről és boldogságról - a pénzügyi válság után. Manager Könyvkiadó, Budapest.

Tracy, B. (2013) (eredeti: 2004): Az eladás pszichológiája - hogyan értékesíthetsz többet, könnyebben és hatékonyabban, mint valaha gondoltad volna? TRIVIUM Kiadó, Budapest.

Tumin, M. (1967): Social Stratification: The Forms and Functions of Inequality. Prentice-Hall.

Weber, M. (1968): Economy and Society. New York, Bedminister Press.

World Development Report 2015 - Mind, Society and Behavior, 2015, WB-Washington D.C. http://www.worldbank.org/content/dam/Worldbank/Publications/ WDR/WDR\%202015/WDR-2015-Full-Report.pdf (utolsó letöltés dátuma: 2019. április 15.) 